\title{
Splitting from Halley: Doing Justice to Race, Unwantedness, and Testimony in Campus
}

\author{
Rosanne Kennedy and Hannah McCann
}

\begin{abstract}
This paper takes the documentary film the Hunting Ground, and the controversy it provoked, as a starting point for interrogating approaches to the representation and regulation of sexual assault on campus. We focus on the work of critical legal theorist Janet Halley, who has been a leading and contentious figure in advocating against the film and for a reconsideration of how Title IX is implemented on university campuses. In 2015, nineteen Harvard law professors, for whom Halley was the spokesperson, issued a press release objecting to the Hunting Ground for misrepresenting the case of one of their students. The discourse surrounding the memo condenses and continues a long and fraught history in which gender and race have been pitted against each other in cases of sexual assault. We develop our analysis by reading the Harvard 19 memo and Halley's recent writings on campus sexual assault in light of her earlier work, Split Decisions. We discuss her controversial analytic for defining feminism, her critique of "governance feminism"; her limited discussion of gender, race, and class: and her advocacy against regulating sex that is "merely unwanted." We argue that while Halley invokes the language of intersectionality, she deviates from its core methodological concern - a focus on black women - and devalues women's testimony. Thus, she practices intersectionality-withoutintersectionality, or surface intersectionality. The gaps in her approach reveal that a theory of consent is needed that does not bracket off the question of unwantedness as "mere" and that engages with complex questions of power and positionality beyond surface intersectionality.
\end{abstract}


Amid a quickly changing landscape around sex and consent, the university campus - with its duty of care for and remit to educate young people - has become an exemplary site for discourse, activism, and regulation of sexual harassment and assault. Sexual assault on university campuses in the United States has been a visible issue for some time, as evidenced by the release of the American documentary The Hunting Ground (2015). Based on interviews with students, the film suggests that there is a rape epidemic on university campuses in the US. It alleges that universities, concerned with protecting their reputations and maintaining alumni philanthropy, tend to dismiss or cover up student complaints about sexual assault, shielding perpetrators. The film closely follows two young women who mount an activist campaign based on protections mandated by Title IX of the Education Amendments of 1972, a federal law that prohibits discrimination on the basis of sex in federally funded education programs. ${ }^{1}$ Students can sue their universities if their policies or implementation of policies are in breach of Title IX, though the implementation of this law is currently being debated under the Trump presidency. ${ }^{2}$ While the film draws on US cases and law, it has been screened on campuses in various countries such as Canada, the United Kingdom, and Australia and has been influential in shaping the discourse on campus sexual assault. ${ }^{3}$ As universities grapple with their responses to sexual harassment and assault on campus, it is timely to delve into the prolific debates on this subject that have been unfolding in the US.

As a means of investigating the stakes involved in representing and responding to allegations of sexual assault on campus, we consider The Hunting Ground and the controversy it provoked via a critical engagement with the work of Janet Halley. We recognize that Halley's 2006 polemical Split Decisions: How and Why to Take a Break from Feminism has been extensively critiqued for misrepresenting feminism (see e.g., Bartow 2008; Jagose 2009; Thornton 2010). We return to her work, however, as she is a key player in campus sexual assault discourse, as evidenced by the academic and practical role that she continues to play in these debates. Of particular relevance, in 2015 she acted as a figurehead for nineteen Harvard law professors who issued a press release denouncing The Hunting Ground. ${ }^{4}$ Their critique centers on the film's representation of a case involving two black Harvard law students, Kamilah Willingham and Brandon Winston, and Willingham's white female friend (Gersen 2015; Yoffe 2015). Colloquially known as the Harvard 19, the signatories to the memo allege that the film is a "purported documentary" and "propaganda" that "provides a seriously false picture both of the 
general sexual assault phenomenon at universities and of our student Brandon Winston" (Bartholet et al. 2015). We parse the issues raised by the memo through the lens of Halley's critique of feminist approaches to sexual misconduct - which provides us with an opportunity to engage critically with both The Hunting Ground and Halley's other writing on sexuality, feminism, and campus sexual misconduct policies. Adopting the dual method that she advocates in Split Decisions, we offer a reading of The Hunting Ground and Halley's writings that is both generous (a considered account of her argument) and critical (identifying blind spots and conceptual limitations), which we illuminate by drawing on the work of other feminist theorists. In this way, we use Halley's own methods to evaluate her perspective in the debate.

The Hunting Ground and the Harvard 19 memo present three issues that are pressing in discussions of sexual assault today: race, unwantedness, and testimony. In addressing these issues, we pay particular attention to Halley's shifting position on race. Although she acknowledges "class, race, and other key differences" in recent work $(2015,109)$, she fails to consider adequately the experiences of black women, which is the starting point of intersectional analysis as conceived by Kimberlé Crenshaw $(1989,1991)$. By invoking the intersectional call of "class, race, and other key differences" to draw attention to discrimination against black men, Halley makes visible harms experienced by some men but at the cost of eliding concerns raised by women's testimony. Further, we propose that the Harvard 19's framing of sexual assault in terms of force rather than consent is consistent with Halley's concern not to extend sexual assault adjudication to what she calls "merely unwanted" sex $(2016,261)$ - that is, sexual contact or acts that may have been unwanted but in which no physical force was used and no physical injury resulted. The Harvard 19 memo is also consistent with her critique of sexual misconduct policies, which she fears will invite excessive regulation and surveillance, have a negative effect on expressions of sexuality, and will favor complainants. Though Halley offers little consideration of how power and context shape experiences of unwanted sex, we find some value for feminist approaches in her willingness to raise issues that might be otherwise unsayable. Ultimately, however, we argue that Halley's advocacy against regulation participates in a long antifeminist tradition of discrediting and tainting women's testimony (Gilmore 2017).

\section{The Hunting Ground and the Harvard 19}


Among other accounts of sexual assault on campus, The Hunting Ground highlights Willingham's story. She recalls that in January 2011, when she and Winston were students at Harvard Law School, they went out partying with a friend of Willingham's. As represented in the film, during the evening people noticed that Willingham's friend "seemed wasted" and Willingham experienced "a heavy feeling" in the taxi home (The Hunting Ground 2015). At Willingham's apartment, the three piled into her bed; she and her friend passed out. She recounts waking to find Winston on top of her, his hand in her underwear, trying to put a finger inside her. Her friend was partly naked, and Winston admitted to undressing her. When Willingham later texted Winston about the incident, he allegedly replied: "I didn't do anything serious. Maybe put a finger in her V." Willingham took the case to Harvard Law School and Winston was expelled, but a few years later she saw him back on campus. As Willingham expresses in The Hunting Ground, "he's a predator, he's dangerous, and...[having him expelled permanently is] exactly what I want." On her website Willingham states that Winston had committed the alleged assault while she and her friend were passed out and "incapable of consenting," indicating that she regards consent as the crucial issue (Willingham 2016).

As The Hunting Ground filmmakers explain, in September 2011 the Harvard Law Administrative Board recommended that Winston be expelled, with the option to reapply (Dick and Ziering 2016). Winston's subsequent appeal was dismissed, but the Harvard Law faculty intervened, which eventually allowed Winston to return to school. By this time, Willingham had graduated. Willingham filed a complaint under Title IX, and subsequently Harvard Law was required to reform its processes (Dick and Ziering 2016). Simultaneously, Winston was indicted by a grand jury that dismissed all of the charges relating to Willingham and the most serious charges of sexual assault against the other woman. He was tried in a Massachusetts court for the charge of indecent assault and battery. The jurors, however, agreed to convict him on a lesser charge of a nonsexual nature (Yoffe 2015). The Hunting Ground (2015) reports: “A grand jury indicted the accused with felony sexual assault of Kamilah's friend and a jury convicted him of misdemeanor nonsexual assault." This statement could be taken as indicative of the seriousness with which the charges against Winston were investigated. However, coming as it does, after several stories about the failure of the police and authorities to take women's complaints seriously, it implies that this case, too, has been minimized and mishandled. 
As a result of investigations by Harvard, the court, and journalists, additional information about the case emerged that was not presented in the film. Before they went out, Willingham and Winston had done cocaine; while they were out, Winston ran up a bar tab of over $\$ 160$ (Yoffe 2015). What does seem uncontested is that Winston removed some of the clothing (top, bra, jeans) of Willingham's friend; the pair had been kissing earlier in the evening. He may or may not have stroked her breasts and put his finger in her vagina. Judging from the extensive materials online - for instance, the websites of Winston and Willingham, court documents, and numerous articles - it is fair to say that this case would fall into the category that Halley designates as "harder cases" $(2015,110) .{ }^{5}$ Harder cases include those in which all participants were engaged in "extreme drinking and drug use" before sexual contact took place, which has the precise effect of blurring boundaries (or lessening inhibitions) (Halley 2015, 112).

In significant respects, the Winston case is atypical of campus sexual assault cases, which raises the question of why the filmmakers included it. Unlike the other cases in the film, which feature undergraduates - many in the first weeks or year of university - Willingham and Winston were both graduate students. Students featured in The Hunting Ground, and more generally those who allege sexual assault on campus, typically contend that universities ignore or dismiss their allegations. By contrast, Harvard investigated Willingham's allegations thoroughly. That the directors chose to include a harder case - in which the facts were unclear and there was little solid evidence of what occurred - could be seen as potentially undermining the film's argument. Including this case, however, served to underscore two points that are core to the feminist advocacy movement: first, advocacy for the complainant's version of events, and second, that any sexual touching when the receiving party is passed out means that consent cannot be given and therefore that the act constitutes assault. The film does not present Winston's version of events, nor does it consider the multiple harms, and who bore them, that resulted not only from the events of the evening but also from the adjudication of the case in various jurisdictions and its aftermath. By contrast, aiming to rebuild Winston's reputation and coinciding with the release of the film, the Brandon Project website presents documents about the case, emails between Winston and Willingham, and testimonials about his character. It also includes documents about the production process of The Hunting Ground that aim to show that the filmmakers took up the position of advocates for sexual assault claimants rather than seeking out evidence and testimony from those who had been accused. 
The Harvard 19 memo was released in response to The Hunting Ground's portrayal of Winston. Although the memo is brief, it serves its dual purpose of defending Winston and condemning the film, and tacitly challenging the broader feminist advocacy movement aimed at ending rape on campus. Signed by key players involved in Winston's case at Harvard, the memo carries the weight of institutional authority and legitimacy. In language that invites interrogation, the signatories contend: "The film gives the impression that he [Winston], like others accused in the stories featured in the film, is guilty of sexual assault by force and the use of drugs on his alleged victims, and that he, like the others accused, is a repeat sexual predator" (Bartholet et al. 2015). The signatories add that there was "never any evidence that Mr. Winston used force, nor were there even any charges that he used force" and that he was subjected to "a long, harmful ordeal," including a campus sexual assault investigation and a court trial "for no good reason" (Bartholet et al. 2015). The Harvard 19's framing of sexual assault as a matter of force is sharply at odds with feminist approaches that regard nonconsensual sex as assault. The memo's charge that Winston was put through an ordeal "for no good reason" could generously be seen as raising the issue of proportionality in light of the circumstances of extreme drinking and drug-taking. It undermines its accusation of the film's partiality, however, through its own partiality, failing to consider the harm to Willingham and her friend and implicitly dismissing the feminist demand for consent as a baseline in sexual relations.

Another issue at stake in the Winston case is race and how easy it is to destroy the reputation of a black man given a history of ingrained racism and racial profiling. Halley, who led media commentary on the Harvard 19 memo, treats black masculinity as a mitigating factor in the Winston case on grounds that black men are disproportionately accused of sexual assault. Stigmatized by the culture, black men face additional hurdles in substantiating their good reputation and achieving success (Gerson 2015; Yoffe 2015). Responding to the Harvard 19, Willingham points out that she is also black and there has been little concern either for the harm she and the other woman suffered or for her position as a black woman making an allegation against a black man. She challenges the Harvard 19 with invoking race in defense of Winston but ignoring "well-established research on the disproportionate rate at which women of color are sexually assaulted" (Willingham 2016). Willingham's response reveals the need for an intersectional analysis, which considers the interaction of racism and sexism as it impacts on black women. 
It is worth noting that intersectionality, first coined by Crenshaw (1989), was intended as an analytic lens that starts from the position of black women. Crenshaw (1991) examines the ways multiple and intersecting structures of oppression, such as sexism, racism, poverty, and homophobia, interact and compound each other, and play out in the lives and on the bodies of black women. As the term has gained academic currency and has been applied in a variety of contexts outside of a legal sphere, this analytic focus has often been forgotten or occluded, and intersectionality is increasingly understood as describing the multiple facets of identity formation. As Barbara Tomlinson (2017) suggests, this broadening out of intersectional approaches has obscured the racial politics crucial to early intersectional analyses, instead bolstering a dynamic of white managerialism. Significantly, as Crenshaw and others observe, the experience of black women is still rendered invisible today through movements such as Black Lives Matter, which, although founded by three black women, was ignited by the experiences of black men as victims of police violence (Crenshaw 2015; Khaleeli 2016). In 2015 Crenshaw initiated the \#SayHerName campaign precisely to raise awareness of and remember black women and girls who have been victims of police brutality and antiblack violence, thereby indicating the continued salience of an intersectional analysis. Despite the urgency of accounting for intersectional forms of oppression that render black women invisible, however, neither The Hunting Ground nor Halley's commentary engages an intersectional approach.

\section{Halley's Split Decisions}

To better understand the position advocated by the Harvard 19, for whom Halley acted as media spokesperson, we turn to her approach to feminism and sexual assault as articulated in Split Decisions (2006). Returning to this earlier work enables us to chart her theoretical trajectory and provides a basis for evaluating the possible benefits and costs of her approach. Engaging with a limited body of feminist and queer theory by US scholars, Split Decisions maps some feminist and queer approaches to sex and sexuality from the late 1970s to the early 1990s, identifying convergences and divergences between and within feminism and queer theory. Halley (2006) advocates "tak[ing] a break from feminism" on the grounds that feminist approaches particularly in cases involving claims of sexual harassment and injury - favor women without considering the costs and benefits to all parties, including men and institutions. She contends that historically there has been a trend within feminism to argue for the "rigorous regulation of sexual 
life in the name of women" that still persists today $(2006,168)$. She aligns so-called "power feminists" (with Catharine MacKinnon her exemplar) with "governance feminism": feminism that has a will to power and that turns to the state to advance its agenda. Her recent coauthored work Governance Feminism: An Introduction (Halley et al. 2018), reflects her enduring engagement with this concept. Furthermore, in the past decade, she has been involved in adjudicating sexual misconduct cases at Harvard and in reviewing both Harvard University's and Harvard Law School's policies on sexual assault and sexual harassment. Positioning herself as a "feminist governor" $(2015,110)$, she claims to share some feminist concerns regarding sexual assault and acknowledges the power she wields as an adjudicator. Our aim is not to evaluate Halley's later claim to feminism; rather, we return to her explicitly "split" position in her early work to illuminate the limitations both of The Hunting Ground and her own later involvement with sexual misconduct on campus.

Halley proposes a simple test for classifying an approach as feminist. In her view, feminist approaches share three criteria: they presume a fundamental male/female binary (“'m/f”) and a hierarchal relationship of men over women (" $\mathrm{m}>\mathrm{f}$ "), and they advocate for women (“carrying a brief for f") $(2006,17)$. To be clear, Halley is not advocating for but rather diagnosing the $\mathrm{m} / \mathrm{f}$ binary she finds articulated by feminist theorists such as MacKinnon and Robin West. Her reductive definition of feminism can be critiqued from any number of angles, and there are today nuanced feminist and queer theories of gender and sexuality that do not begin with a binary account of sexual difference. Nonetheless, her suggestion that there may be benefits to splitting from a conceptual approach to gender issues that relies on $m / f, m>f$, and carrying a brief for $\mathrm{f}$ (which we may or may not agree is feminist) can be analytically productive. As we demonstrate, this understanding of feminism is operative today in some feminist advocacy movements, as represented, for example, by The Hunting Ground. Halley argues that in cases involving claims of sexual harassment and injury, we ought to take a break from the assumptions of "feminism" (as defined by the above three criteria) to identify more clearly the costs and benefits of any decision and which party will bear or reap them.

Halley contends that a "feminist" assumption of $\mathrm{m}>\mathrm{f}$ has problematic effects in cases in which men are victimized by men. In such instances, male victims are coded in the position of $\mathrm{f}$ for the purpose of understanding experiences of harm. She proposes that maintaining a fundamental belief in $\mathrm{m}>\mathrm{f}$ constitutes a kind of slave morality where $\mathrm{f}$ is always positioned as 
vulnerable relative to $\mathrm{m}$. She also claims that always carrying a brief for $\mathrm{f}$ amounts to an identity politics specifically focused on advocating for women as a subordinated and vulnerable identity. Halley's contention that feminism advocates a politics of female injury can be located within a longer feminist tradition. For instance, Wendy Brown articulates problems with an identity grounded in "wounded attachments" that problematically appeals to the state for protection and redress $(1995,52)$. However, while Brown proposes that feminists can mitigate a politics of injury, Halley worries that a feminist politics of injury risks victimizing men, who may be wrongly accused by women $(2006,58)$. As Halley argues: "Oddly, representing women as the end points of pain, imagining them as lacking the agency to cause harm to others and particularly to harm men, feminist also refuse to see women - even injured ones - as powerful actors" (2006, 346). In other words, Halley suggests that feminism always codes women in the victim position, rendering invisible any possible harm to men.

Similarly, and focusing specifically on the problematic construction of victimhood in discussions of sexual assault, Kristen Bumiller has argued that using regulation to punish accused individuals is a blunt instrument $(1988,89)$. She argues for analysing the interaction of racism and sexism to better understand the social and material conditions that construct persistent stories of a particular form of victimhood while obscuring others. There is, however, a divergence between Bumiller and Halley. Whereas Bumiller is concerned with being better able to account for the testimony of women undistorted by legal requirements, Halley offers counterfactuals that ignore or minimize women's testimony. Further, Bumiller argues that a legal response that focuses on the question of consent misconstrues the experience of sexual assault, which is about survival rather than the negotiation of consent $(1988,77)$. Applying Halley's terms, we see that Bumiller agrees that the $m>$ f view ought to be better interrogated, but she continues to carry a brief for $\mathrm{f}$. In contrast, Halley does not separate out the construction of the injured subject of $m>f$ from carrying a brief for $f$. In rejecting $m>f$, she also appears to reject carrying a brief for $\mathrm{f}$. In other words, her suggestion that we take a break from feminism (as she defines it) must involve taking a break from all three components of "feminist" claims.

\section{Reading The Hunting Ground via Halley}

Though Halley's version of feminism clearly draws on a very limited cannon of Western feminist thought, and liberal feminist perspectives in particular, we contend that her rubric 
nonetheless helps to reveal the limitations of specific responses to sexual assault, as demonstrated in The Hunting Ground. While we recognize that multiple critical lenses may be applied to this film, Halley's rubric $-\mathrm{m} / \mathrm{f}, \mathrm{m}>\mathrm{f}$, and carrying a brief for $\mathrm{f}-$ offers one possible lens for analysis that highlights the limitations of the film's framing of gender and power.

First, sexual assault is seen as a form of gendered violence perceptible along the lines of $\mathrm{m} / \mathrm{f}$ only, where men who experience it are coded in the " $\mathrm{f}$ " position. The film manifests this binary conception by presenting the testimony of male victims in the middle of the documentary, smoothly transitioning from women to men's testimonies. Aside from acknowledging the differential stigma that surrounds male survivors, the film does not offer an account of how sexuality or other aspects of embodied gender, gender diversity, or any other dynamics relating to sexuality or gender may play a role in experiences of assault.

Second, though the film acknowledges that men may experience sexual assault, the fundamental adherence to $\mathrm{m}>\mathrm{f}$ persists insofar as there is a coding of women as vulnerable prey throughout the film. The title introduces a gendered binary of male hunter and female prey. ${ }^{6}$ The gendered connotations of hunter/hunted are conveyed in the opening footage of women opening their college acceptance letters, in which the only white man represented in the montage appears in grainy CCTV-like footage, as if stalking around a neighborhood. This commitment to $\mathrm{m}>\mathrm{f}$ alongside $\mathrm{m} / \mathrm{f}$ in the film suggests that women cannot be the perpetrators of harm.

Third, the film carries a brief for $\mathrm{f}$. The emphasis is on female survivors, and the filmmakers showcase statistics that position women as the beneficiaries of their main brief. While acknowledging that men who are sexually assaulted are less likely to report their experiences, the film does not consider the intersecting factors that may lead to men underreporting (such as concerns regarding sexuality). Rather, it foregrounds the need to respond effectively to sexual assault primarily for the benefit of women on campus. In identifying the feminist commitments of The Hunting Ground we are not suggesting that the film ought to have favored a different group than women. Rather, Halley's lens enables us to interrogate the film's commitment to $\mathrm{m} / \mathrm{f}, \mathrm{m}>\mathrm{f}$, and carrying a brief for $\mathrm{f}$, and to show how this gendered framing may obscure other experiences of and issues relating to sexual assault.

In addition to flattening experiences of sexual assault along an $\mathrm{m}>\mathrm{f}$ binary, one of the key issues that The Hunting Ground overlooks is the intersecting effects of racism and sexism as they affect both black men who are accused of sexual misconduct and black female complainants. 
The film represents race through the lens of diversity rather than intersectionality. In adopting gender as a singular analytic lens, the film adopts a postracial position. Diversity has been criticized as a neutral language that replaces the political language of oppression, racism, and social inequality associated with demands for social justice. Without deeper intersectional considerations, diversity "individuates difference, conceals inequalities and neutralizes histories of antagonism and struggle" (Ahmed and Swan 2006, 96).

Despite representing some diversity of students, the film arguably tries to neutralize intersections of race and gender by leaving out discussions of race altogether, and it thereby leaves the dominant framing of race intact. For example, the film introduces a case in which a white woman accuses black American football star Jamie Winston of sexually assaulting her and the university of ignoring her claims. The failure to address the impact of race when reporting crimes where black men are represented as perpetrators serves to subtly reinforce preexisting prejudices. As Jessie Daniel contends, "While some may applaud such a "colour-blind" approach, the vacuum left in the absence of any kind of analysis...reifies the messages inscribed in the images of white victims and Black perpetrators replayed again and again on the evening news" $(1997,83)$. The film's inability to consider intersectional issues, or to consider the effects of racial prejudice on black men accused of sexual misconduct, continues a tradition wherein race and gender have been pitted against each other in cases of sexual assault and harassment (Duru 2004). ${ }^{7}$

As the above analysis demonstrates, Halley's rubric of feminism (as she defines it) is useful for analyzing the limitations of representations of sexual assault, such as depicted in The Hunting Ground. We now turn, however, to the limits of Halley's theoretical position, considering not just what she advocates against but the problems of what she advocates for.

\section{The issue of unwantedness}

As we demonstrate above, Halley's rubric may be a productive way to deconstruct the binary assumptions underlying some representations of sexual assault. A close reading of her own application of her rubric, however, reveals her problematic attachments and omissions. Here we interrogate her conceptual approach as it relates to her defence of Winston and to her critique of sexual misconduct regulation more broadly. Of particular relevance, she introduces two terms "unwantedness" and the "problematic of wantedness" $(2006,302)$ - that are crucial for 
understanding her approach to questions of sexual injury. Halley introduces these terms near the end of Split Decisions, in her discussion of Oncale v Sundowner, a 1998 Title VII case. Joseph Oncale's complaint against his employer was based on the premise that his harassment his male coworkers on an oil rig constituted discrimination on the basis of sex. Referring to "Oncale's...allegation of unwantedness" (2006, 295), Halley introduces the undertheorized term "unwantedness." Putting to one side Oncale's claim of unwantedness as "a mere allegation" (2006, 295), she suggests various counterfactual readings, which she contends are consistent with the facts of the case. Her concern is to explore the various dynamics that, however unlikely given the facts, could have been in play (for example, a fetishization of masculine/feminine roles where Oncale invited attention from other men but later regretted it) to trouble a simple $\mathrm{m} / \mathrm{f}$ binary that would code Oncale in the " $\mathrm{f}$ " (victim) position. By putting aside questions of wantedness/unwantedness, Halley advocates for "sexuality as a dark power," that is, imposing less regulation on (what might be) "edgy" or dynamic sexual encounters $(2006,301)$.

Halley does not specify precisely what she means by unwantedness. Instead, she introduces two other terms, "problematic sex" and "the problematic of wantedness," which provide limited insight. She describes problematic sex as an "edgy experience" that is "probably cherished by more people than are willing to say so" $(2006,302)$. She does not define the problematic of wantedness, but some direction is provided in her favorable citation of the prosex writings that emerged during the feminist "sex wars" of the 1980s. According to Halley, prosex activists "affirmed that women sometimes are subjected to sexual injury by men, and that sex is a place where harmful dominance and submission can happen. Danger is real.... But they tended to say that [danger] is bad not because it realizes male dominance, but because it deters women from being sexually adventurous, from seeking and finding pleasure" $(2006,117)$. One issue at stake in the sex wars was whether women could and should get pleasure from sexual scenarios that eroticized male dominance and female submission. Halley appears to extrapolate from this issue her conception of the problematic of wantedness - complicated dynamics that render sex simultaneously wanted and unwanted - to advocate for less strict boundaries on what is acceptable in sexual encounters and, particularly, what kinds of sexual behavior and events should be actionable.

Underlying these issues, though not always explicitly discussed by Halley, is the concept of consent. While consent is a key issue in feminist discussions of sexual assault, in Split 
Decisions Halley does not address the connection between unwantedness and consent. In later writing she states that she would not want to have sex that is nonconsensual, yet she is concerned with a more fundamental threat: what she calls "the weight of the state" in sexual encounters $(2016,258)$. Here she draws a line between "merely unwanted" sex and rape as sex achieved by force $(2016,261)$. To understand Halley's concern with state regulation extending its reach, we can productively return to Split Decisions, where she contends that regulation in cases such as Oncale risks the implementation of "a vanilla sex-regime": "[Regulation] might turn the normative screw in the direction of less problematic sex, making problematic sex more unwanted by more people, and increasingly more actionable.... There are lots of people out there...I am one of them — who think the problematic of wantedness isn't just tolerable; we think it's beautiful; it's brave; it's complicated and fleeting and elaborate and human" $(2006,301)$. While Halley's contention that the problematic of wantedness is beautiful remains opaque, reading generously, we might regard her position as a response that challenges normative sexual moral codes. Defending openness to uncertainty and unwantedness as integral to deep sexual intimacy, she aims to open a space for considering that what may be allegedly unwanted in sex may be secretly desired or ambivalently sought. Her work resonates with other queer theorists such as Lauren Berlant and Lee Edelman (2014) who have argued for seeing the negativity at the heart of sexual desire. Halley suggests, "I think most of us experience sex (when it's not routinized) as an alarming mix of desire and fear, delight and disgust, power and surrender, surrender and power, attachment and alienation, ecstasy in the root sense of the word and enmired embodiedness" $(2006,302)$. Her broader point is that regulating problematic sex might have a profound effect on private experiences of sex and thereby risk making sex more banal. She cautions that excessive policies regarding sexual conduct might decrease the willingness of participants to engage in edgier, boundary-crossing experiences, which may produce shame but also pleasure.

In imaging these scenarios, however, Halley invites us to doubt testimony from those alleging sexual assault. She does not consider the conditions where "mere unwantedness" might slip into coercive or even violent sex. Following Halley's line, we may end up with no definition of rape (whether by force or otherwise). Her suggestion that affirmative consent regulation risks a "moral order" that is "repressive and sex-negative" $(2016,259)$ begs the question of whether, by her standards, rape should be defined or adjudicated at all. 
Despite Halley's prevarications, parsing her position on unwantedness is crucial for making sense of the Harvard 19's defense of Winston. The Winston case could be framed in terms of what Halley calls "unwanted sexual contact" $(2016,264)$. Halley's defense of Winston does not, however, appear to be motivated by advocacy for edgy sex, but rather by a strong commitment to mitigating the harms that follow from disciplinary processes, especially in cases when race may compound the issue of fairness or when unwanted sex occurs in the context of extreme drinking. Furthermore, the memo's advocacy for Winston is consistent with Halley's concern regarding male victimization. In Split Decisions, she contends that the politics of injury as articulated by Brown and others can be extended to include "male victimization" $(2006,58)$. By male victimization, Halley is not referring simply to the fact that men may experience sexual assault but rather to the harm that may be done to male defendants (such as Winston) through disciplinary processes and court proceedings. Her rubric of mere unwantedness and her advocacy for those accused of sexual assault, however, has a cost she only fleetingly acknowledges: that dismissing allegations of unwanted sex may, in turn, harm complainants.

\section{Splitting from Halley}

Unwantedness echoes the concept of "gray rape," characterized by blurred lines of consent (Alcoff 2011, 2018). As Linda Martín Alcoff outlines, "In recent years young activists and victims have introduced the term 'gray rape' to capture the complexity of some events" (2018, 9). Unlike Alcoff, who calls for better interrogation of the grey areas of sexual encounters, Halley advocates for rather than against blurred lines. Halley's work - engaged with debates from the sex wars of the 1980s - reads as particularly jarring in the age of \#MeToo. We read Halley as unwilling to acknowledge the importance of feminist perspectives on power and subordination. For example, in Split Decisions she outlines Gayle Rubin's groundbreaking essay "Thinking Sex" (1992), praising its call to attend to questions of sexuality separately from feminist theorizations of gender. For Halley, however, Rubin does not go far enough, given that she "assume[s] that a left progressive pro-sex movement must think and act on the basis of a subordination theory" $(2006,118)$. Consulting the original article from Rubin, we see this seeming attachment to subordination theory play out via her claim that "a democratic morality should judge sexual acts by the way partners treat one another, the level of mutual consideration, the presence or absence of coercion, and the quantity and quality of the pleasures they provide" 
(1992, 283). While Rubin makes the case against moral panics around sexuality and advocates for loosening normative boundaries regarding sexual acts, she does not obfuscate or downplay issues of consent and power. Rather, she maintains a position consistent with an ethics of selfcare and care of the other. In contrast, it seems that troubling boundaries around sex is precisely what Halley seeks to achieve in Split Decisions by way of her critique of theorists such as Rubin, whom she sees as too closely wedded to "feminist" theory.

Halley's defence of unwantedness is further limited by her failure to consider or analyze issues of power or context. What might be sexy for someone in a dominant position may of course be experienced as a violation for someone on the receiving end. Halley, however, treats all players as if there are no power differentials. For instance, in one of the few occasions on which she mentions power in Split Decisions, Halley approvingly cites Duncan Kennedy: “Kennedy turns (quite appropriately, it seems) from MacKinnon's top-down model of power to an idea of its 'interstitial' form, and even to the formulation of 'pleasure/resistance' operating not against power from below, but from within it" $(2006,191)$. This endorsement of a Foucauldian conception of power in Kennedy's work does not sufficiently substitute for a careful analysis of unwantedness that considers differences in the positions and resources of parties involved in a sexual interaction. Halley simply uses the largely unclarified rhetoric of "edgy sex" and "problematic sex" to describe what others may definitively regard as unwanted sex. Understandably, people involved in adjudicating campus sexual assault may want clearer guidance. Is sex problematic only when it involves violent or dangerous acts, and what constitutes danger? Or when one party pressures another into participating in or performing an unwanted act? Or when one party is not capable of consenting? Or because it crosses cultural taboos, including cross-racial or religious barriers, age barriers, or incest? The range of issues that make sexual contact problematic cannot be reduced to an all-encompassing category of unwantedness.

In more recent writings, Halley has continued to defend unwantedness. Following the initiation of Title IX cases in university settings in the early 2000s and the first affirmative consent law (the "Yes Means Yes" bill) in California in 2014, Halley turned her attention to institutional regulatory frameworks and advocated for more analysis of consent from a legal realist perspective in university settings (Halley 2016). She argues that for MacKinnon and others, "emancipation is a world in which women have sex only when they desire or want it. To 
move us closer to such a world, law should impose sanctions on men who have sexual contact with women who didn't desire or want it” $(2016,260)$. Key to advancing this goal, Halley contends, was "securing a definition of a new civil rights violation, sexual harassment, in which the wrongful act is unwanted sexual conduct" (260). There are two issues in contention here: first, women's agency to determine when, whether, and what kind of sex they want to engage in, and second, whether the law should be used to adjudicate unwanted sexual encounters. Recently Halley has explicitly argued for relaxing the standards for legal tests of sexual harassment and sexual assault $(2016,260)$. She also considers the limits of a feminist approach to a series of "harder cases" involving, for instance, voluntary extreme drinking and drug-taking by both complainant and respondent or cases in which, although an assault has occurred, there is insufficient evidence to identify the perpetrator(s) or to establish what happened $(2015,103)$.

In these and other writings, she critiques affirmative consent policies and articulates her concern that the extensive governance powers granted by Title IX will be used by "feminist governors" on campus to further a narrowly feminist advocacy agenda, rather than considering the costs and benefits to all parties involved $(2015,114)$. Insisting on the need for a 'reasonable person' test to determine if sexual harassment has been persistent and has created a hostile climate on campus, she ardently rejects sexual misconduct policies that gauge unwantedness on the basis of the complainant's subjective claim alone $(2016,260)$. Further, she objects to campus policies that "make it far easier to hold accused men responsible for sex that was merely unwanted" $(2016,261)$. Halley's rhetoric of "mere" unwantedness minimizes not only the damage done to complainants but also their agency in choosing what kind of sexual encounters they desire.

\section{Sexual assault as more than black and white}

While we see Halley's defence of unwantedness operating in the background of her approach to the Winston case, her later (2015) work explicitly identifies the risk of racial profiling and consequent harm as the basis for advocating a cautious approach to sexual assault adjudication. Halley contends that black men are disproportionately targeted in campus sexual assault allegations and are more likely than men of other ethnicities to be caught in the carceral net. She cautions that feminist governors will make assumptions that favor the injured female complainant without assuring fairness for all students on campus, particularly black men (2015, 
114). Acknowledging the violence done to black men by false accusations in cases of rape and sexual assault, most typically involving white women, she urges that campus bodies tasked with monitoring and adjudicating sexual misconduct proceedings should practice vigilance regarding disproportionate racial impact. Based on her experience in dealing with sexual assault matters at Harvard, she contends that since Title IX deals only with sex discrimination, interpreted by university policies as sexual and gender-based harassment, campus bodies typically do not monitor for racial bias. She proposes that cases should go to a campus body tasked with assuring fairness for all involved in sexual misconduct investigations, including the defendant as well as the complainant.

Given her more recent concern with the impact of sexual assault allegations on black men, it is worth tracking the way race has figured in Halley's corpus. In Split Decisions, she is only interested in race and gender to the extent that they enable her to map the shift from convergence to divergence in feminist theory in the late 1970s. She takes the well-known Combahee River Collective Statement (1977) as her example of how even feminists who value convergence inevitably diverge when faced with competing oppressions such as patriarchy and racism. Surprisingly, given her self-identification as a critical legal theorist, Halley does not discuss Crenshaw's influential (1989) concept of intersectionality, which provides an alternative conception of and approach to the relationship between gender and race. By adopting a malecentric approach to race and gender, Halley offers us a version of intersectionality-withoutintersectionality, or what we call surface intersectionality.

Given this context, Halley's defence of alleged perpetrators through evoking questions of minority status warrants further examination. She calls on us to better attend to questions of race in matters of campus sexual misconduct but does little to assist those making allegations of assault, who may be women of color. The effect of this separation of gender and race, as Bumiller (1988) suggests, is that intraracial sexual assault is rendered invisible. As she observes, sexism and racism are often presented as diametrically opposed, rather than as interconnected: "Liberal politics encourages us to find a trade-off between the feminist interest in ensuring that offenders are punished (security) and antiracist claims that excessive state power is exercised against blacks (freedom)" $(1988,88)$. Rather than take on board this critique, Halley focuses exclusively on the position of black men with no consideration for black women. Ironically, her one-sided approach reinstates $m>f$ by making visible the possible harms to men that follow from 
allegations of assault at the cost of silencing women's testimonies of harm. In particular her habit of invoking race without undertaking a thorough intersectional analysis reinforces existing structural logics that further delegitimize minority women's voices and leaves her with little to say about the position of women of color.

\section{The brief for $f$ and the problem of testimony}

While Halley - at surface level - warns of the dangers of a narrow gender analysis of sexual assault, we are concerned that she appears to carry a brief against $\mathrm{f}$ that is made possible by her invocation of intersectionality-without-intersectionality. Halley's position reproduces and corroborates a stereotypical image of women as unreliable witnesses who are likely to make false or frivolous allegations against innocent men - what Leigh Gilmore has called the "tainted witness" (2017). Missing from Halley's account is a consideration of the treatment of women's testimony by the law, both in courts and in parajudicial settings such as senate or campus hearings. Also missing is a consideration of how young women are taking matters into their own hands, which complicates how we must understand carrying a brief for $\mathrm{f}$.

In Split Decisions Halley maps what she sees as two key strands of feminism - "power feminism" and "cultural feminism" - that adhere to a model of male power $(m>f)$, and that carry a brief for $\mathrm{f}(2006,41)$. She claims that they have come to dominate as feminism has been absorbed institutionally and in regulatory settings, a phenomenon she calls "governance feminism" $(2006,20)$. This mapping, however, engages with a battle of feminism past, and not the present era of feminist activism. In the introduction to the special issue in which Halley's article on affirmative consent was published, Suzanna Danuta Walters voices her concern that “the ghost of the sex debates haunts...[Halley's] piece too deeply. Is 'yes means yes' the next iteration in repressive and neo-Victorian imaginings of women's sexuality? Or could it also be the honest efforts of activists to reconceive sexuality in a context of pervasive violence?" (2016, 7). While Halley credits feminism with rewriting campus sexual assault and affirmative consent policies, she fails to acknowledge that institutions are being forced to respond to these issues as a result of a groundswell of complaints made by students, not "feminist governors." We might read The Hunting Ground not as advocating for the state to intervene on university campuses from above but rather as documenting feminism from below, with students seeking to use Title IX to compel universities to respond to their unheard or dismissed complaints. 
Although Halley claims that feminism has various institutions under control, the outcome of recent cases involving sexual assault suggests otherwise. Dismissing the feminist framework of $\mathrm{m}>\mathrm{f}$, she invokes in its place a scenario of $\mathrm{f}>\mathrm{m}$. This lens dangerously misrepresents the hierarchies of power in sexual assault cases, even where the dynamics involved are more complex than $\mathrm{m}>\mathrm{f}$ would allow. In Winston's case, for instance, both the law school and the formal institution of the law ruled, at least partially, in his favor. This result suggests that these institutions have not been ruled by "dominance feminism” as Halley suggests.

Similarly, the lenient sentencing of Brock Turner - a case that was far less "gray" than Winston's - indicates that the balance of institutional power has not been historically tipped in favor of outcomes for women. In 2016, the trial and conviction of Turner, a student swimmer at Stanford University, drew significant attention to the way campus sexual assault was adjudicated. His sentence, reduced to six months in a county jail, sparked intense controversy, especially after the victim released an impact statement on social media. The trial, sentencing, media commentary, and personal statements were parsed and parlayed, rendering experiences of law as they impact on both complainant and defendant open to scrutiny. The man responsible for Turner's light sentence, Judge Aaron Persky, has since been recalled by voters. Like the events documented in The Hunting Ground, the recall of Judge Persky reveals the power of activism from below in a post-\#MeToo landscape rather than power wielded by "feminist governors." The Turner case reflects that formal legislative power has not historically weighed in favor of women in the way that Halley imagines.

We can further interrogate the limits of Halley's vision with examples of young women's testimonies in order to assess what is at stake. As the young woman in the Turner case states, "You knocked down both our towers... Your damage was concrete: Stripped of titles, degrees, enrollment. My damage was internal, unseen...Y You took away my worth, my privacy, my energy, my time...my own voice, until today" (in Baker 2016). Similarly, Willingham responded to the Harvard 19 press release, stating, "I am tired of being treated as if I don't matter.... I am angry with you for forcing me, as my assailant did, to assert my value. But, most importantly, I am not alone. I am only one of the increasing number of survivors who reject the silence that you... are trying to impose (Willingham 2016, emphasis added). As these testimonies demonstrate, what is at stake for these young women is respect, bodily integrity, and recognition of their worth. They seek a sign from institutions, and from the men involved in the cases, that 
they are valued as members of society and that their bodies are not available to be groped, undressed, manipulated, or penetrated when they refuse or are unable to consent. In Halley's insistence that we take a break from carrying a brief for $\mathrm{f}$, we risk adding to the silencing of women and inadvertently carrying a brief for the reputations of institutions and men who already hold the balance of power.

There must be an interrogation of the power relations that are entangled in who is able to speak, and who is able to be heard. Such an approach would trouble Halley's claim that feminists risk producing harm by creating a discourse around sexual assault. As Sara Ahmed implores us to ask, "Does bad feeling enter the room when somebody expresses anger about things? Or does the entry of anger simply mean that the bad feelings that circulate through objects get brought to the surface in a certain way? The feminist subject in the room hence brings others down, not only by talking about unhappy topics such as sexism but by exposing how happiness is sustained, by erasing the signs of not getting along" $(2010,582)$. Feminists point out the bad feelings (for example, of victimization) already in circulation around sexual assault, but this does not mean they produce these feelings. ${ }^{8}$

Willingham's case against Winston did not proceed to trial; he was tried only for charges relating to her friend. Given the doubt cast on Willingham's testimony by the Harvard 19, who were her teachers as well as Winston's, and in the public sphere through articles in venues such as the New Yorker, Slate, and Winston's website, it is not surprising that she sought "adequate witness" elsewhere. An adequate witness "receive[s] testimony without deforming it by doubt, and without substituting different terms of value for the ones offered by the witness herself' (Gilmore 2017, 5). The directors of The Hunting Ground provided a venue through which the testimony of self-identified survivors such as Willingham could find adequate witness. Conceiving of the film as feminist advocacy, they provided a platform for victims and survivors to tell their stories of harm, creating "a holding environment for testimony" (Gilmore 2017, 5). Whereas Brown and others have argued against an identity grounded in wounded attachments, survivors today speak for themselves and resist having their discourse mediated by an expert (Alcoff and Gray 1993). Women whose stories appear in The Hunting Ground are in leadership positions in advocacy organisations such as End Rape on Campus, speaking positions that mobilize relations of power/knowledge. One dimension of this power is to determine where lines 
should be drawn between acceptable messiness and unpredictability in sexual relations and conduct that is unacceptable.

\section{Conclusion: The benefits and costs of Halley's approach}

Halley argues that with regulation the problematic of wantedness will not go away but will be driven below the surface $(2006,301)$. She assumes that the effects of regulating sex will force questions of sex and desire further into the realm of the private. As we see in debates around sexual assault on campus and the \#MeToo movement, however, calls to regulate sex unearth the political and public dimensions of that which would otherwise be considered private. As demonstrated in the recent Senate Judiciary Committee hearing on September 27, 2018, at which Dr. Christine Blasey Ford gave testimony of an alleged sexual assault by Supreme Court nominee Brett Kavanaugh, sexual encounters previously considered private have become intensified as a subject for public discussion. Feminist activism from below has created a public space to name such experiences and require powerful bodies, including the law, to respond.

Reading both with and against Halley, from Split Decisions to her discussions of sexual assault on campus, enriches our understanding of the interstices in current sexual assault

discourse (including Halley's own). She points us in some helpful critical directions for assessing representations and regulatory responses to sexual assault. We need not agree with her contention that feminism always maps women onto the position of victim, yet this rhetorical strategy allows us to identify where such framings might be playing out and the limits of these framings. Viewing The Hunting Ground via Halley's rubric of feminism, for instance, reveals some of the blind spots that may emerge from a framework of $\mathrm{m} / \mathrm{f}, \mathrm{m}>\mathrm{f}$, and carrying a brief for f. Such framings - which Halley calls feminist - risk erasing the complicated intersections and difficult questions around harm that may emerge in sexual assault cases.

Through her challenges, Halley draws our attention to conceptual underpinnings that we might not want to see. As such, her rubric has particular significance for responding to discourse around sexual assault in a post-\#MeToo world: whose stories are rendered invisible, and who has the power? What hard issues around desire, subordination, and dominance are currently being absorbed by a homogeny of \#MeToo discourse? Which hard cases might be yielding uneven treatment under the law, in the media, on campus, or in other institutional settings? Halley's later work highlighting the disproportionate focus on black men as perpetrators calls us to remember 
difficult histories where race and gender have intersected to produce negative outcomes for accusers and accused alike. Yet the gaps in her own invocations reveal that a theory of consent is needed that does not bracket off the question of unwantedness as "mere" and that engages with complex questions of power and positionality beyond surface intersectionality.

While some of Halley's ideas might have theoretical appeal, her own application of her theory skews toward favoring the accused. This tendency foreshadows scenarios where the reputation of men and institutions is pitted against respect for women and their testimony. This very issue has been magnified in the Senate Judiciary Committee hearing for nominee Kavanaugh. Defending himself against Dr. Ford's testimony, he played the loss of reputation card to win the empathy and support of his colleagues.

While we take issue with many of the conclusions that can be drawn from Halley's work, she ought not be readily dismissed, particularly given her prominent public voice in the campus debate. Notably, her approach is not purely theoretical but has material consequences for people involved in incidents of sexual assault on campus. For instance, her involvement in the Winston case shows that she is able to recruit supporters for her position. Moreover, as a Harvard Law School professor she has advocated for changes to sexual misconduct policy with some authority. As we have shown, her relentless critique of carrying a brief for $f$ may lead to a path to carrying a brief against $\mathrm{f}$, such that the historically dominant dismissal of women's testimony in sexual assault cases is maintained. This is indeed troubling. We also challenge her superficial invocation of an intersectional lens without fully engaging in the project of intersectionality.

What we are left with following a close reading of Halley, and reading Halley against herself, is not a clear split from her work. Rather, we hope that our engagement has opened a space to consider an approach to sexual assault regulation and discourse that attends to the dynamics of multiple forms of oppression in careful ways. To do justice to questions of race, unwantedness, and testimony, greater attention to the complex machinations of power, advocacy, and attachment to certain positions and voices is required. We must reflexively attend to who the brief is carried for and who may be left silent.

\section{References}

Ahmed, Sara. 2010. "Killing Joy: Feminism and the History of Happiness." Signs: Journal of Women in Culture and Society 35(3):571-94. 
Ahmed, Sara, and Elaine Swan. 2006. "Doing Diversity." Policy Futures in Education 4(2):96100.

Alcoff, Linda Martín. 2011. "When Culture, Power and Sex Collide" New York Times, June 8. https://opinionator.blogs.nytimes.com/2011/06/08/when-culture-power-and-sex-collide/

- 2018. Rape and Resistance: Understanding the Complexities of Sexual Violation. Cambridge: Polity.

Alcoff, Linda Martín, and Laura Gray. 1993. "Survivor Discourse: Transgression or Recuperation?”Signs 18(2):260-90.

Australian Human Rights Commission. 2017. "Changing the Course: National Report on Sexual Assault and Sexual Harassment at Australian Universities." Sydney: Australian Human Rights Commission. https://www.humanrights.gov.au/sites/default/files/document/publication/AHRC_2017_C hangeTheCourse UniversityReport.pdf.

Baker, Katie J. M. 2016. "Here Is the Powerful Letter The Stanford Victim Read Aloud to Her Attacker." Buzzfeed, June 3 https://www.buzzfeed.com/katiejmbaker/heres-the-powerfulletter-the-stanford-victim-read-to-her-ra?utm term=.jgLB0dm5B\#.beaO3P9NO.

Bartholet, Elizabeth, Scott Brewer, Charles Donohue Jr., Nancy Gertner, Janet Halley, Bruce L. Hay, Philip B. Heyman, et al. 2015. "Re: The Hunting Ground." Press Release, November 11. http://brandonproject.org/wp-content/uploads/2015/11/NewHLSPressRelease.pdf.

Bartow, Ann. 2008. "Review Essay: Janet Halley, Split Decisions: How and Why to Take a Break from Feminism." Windsor Yearbook of Access to Justice 36(2):391-97.

Berlant, Lauren Gail, and Lee Edelman. 2014. Sex, or the Unbearable. Durham, NC: Duke University Press.

Brown, Wendy. 1995. States of Injury: Power and Freedom in Late Modernity. Princeton, NJ: Princeton University Press.

Bumiller, Kristen. 1988. "Rape as a Legal Symbol: An Essay on Sexual Violence and Racism." University of Miami Law Review 42(75):75-91.

Crenshaw, Kimberlé. 1989. "Demarginalizing the Intersection of Race and Sex: A Black Feminist Critique of Antidiscrimination Doctrine, Feminist Theory, and Antiracist Politics." University of Chicago Legal Forum 1989: 139-67 
_ 1991. "Mapping the Margins: Intersectionality, Identity Politics, and

Violence against Women of Color." Stanford Law Review 43(6):1241-99.

—. 2015. "Why Intersectionality Can’t Wait”. Washington Post, September 14.

https://www.washingtonpost.com/news/in-theory/wp/2015/09/24/why-intersectionalitycant-wait/?utm term $=. \mathrm{d} 2 \mathrm{~b} 7094 \mathrm{~b} 0 \mathrm{c} 3 \mathrm{f}$.

Daniels, Jessie White. 1997. Lies: Race, Class, Gender and Sexuality in White Supremacist Discourse. London: Routledge.

Dick, Kirby, and Amy Ziering. 2016. The Hunting Ground: The Inside Story of Sexual Assault on American College Campuses. New York: Hot Books

Duru, N. Jeremi. 2004. "The Central Park Five, the Scottsboro Boys, and the Myth of the Bestial Black Man." Cardozo Law Review, no. 25: 1315-65.

End Rape on Campus. 2017. http://endrapeoncampus.org.

Frye, Marilyn. 1993. "Some Reflections on Separatism and Power." In The Lesbian and Gay Studies Reader, edited by Henry Abelove, Michèle Aina Barale, and David M. Halperin, 91-98. New York: Routledge.

Gersen, Jeannie Suk. 2015. "Shutting Down Conversations about Rape at Harvard Law." New Yorker, December 11. http://www.newyorker.com/news/news-desk/argument-sexualassault-race-harvard-law-school.

Gilmore, Leigh. 2017. Tainted Witness: Why We Doubt What Women Say about Their Lives. New York: Columbia University Press

Halley, Janet. 2006. Split Decisions: How and Why to Take a Break from Feminism. Princeton, NJ: Princeton University Press.

----- 2015. "Trading the Megaphone for the Gavel in Title IX Enforcement." Harvard Law Review Forum, no. 128: 103-17.

----- 2016. “The Move to Affirmative Consent.” Signs 42(1):257-79.

Halley, Janet, Prabha Kotiswaran, Rachel Rebouché, and Hila Shamir. 2018. Governance Feminism: An Introduction. Minneapolis: University of Minnesota Press.

Harris, Kate Lockwood. 2011. "The Next Problem with No Name: The Politics and Pragmatics of the Word Rape." Women's Studies in Communication 34(1):42-63. 
The Hunting Ground. 2015. Directed by Regina Kulik Scully, Paul Blavin, Kirby Dick, Amy Ziering, Thaddeus Wadleigh, Aaron Kopp, and Miriam Cutler. Sausalito, CA: Ro*Co Films Educational.

The Hunting Ground Australia Project. 2017.

http://www.thehuntinggroundaustralia.com.au/participating-universities/

Jagose, Annamarie. 2009. “Feminism's Queer Theory.” Feminism \& Psychology 19(2):157-74.

Khaleeli, Homa. 2016. “\#SayHerName: Why Kimberley Crenshaw Is Fighting for Forgotten Women." The Guardian, May 30.

https://www.theguardian.com/lifeandstyle/2016/may/30/sayhername-why-kimberlecrenshaw-is-fighting-for-forgotten-women.

NPR (National Public Radio). 2017. "Betsy DeVos Launches Reform Effort on Campus Sexual Assault Policy." All Things Considered, September 26.

https://www.npr.org/2017/09/26/553799166/betsy-devos-launches-reform-effort-oncampus-sexual-assault-policy.

Oliver, Kelly. 2016. Hunting Girls: Sexual Violence from The Hunger Games to Campus Rape. New York: Columbia University Press.

Gayle, Rubin. 1992. "Thinking Sex: Notes for a Radical Theory of the Politics of Sexuality." In Pleasure and Danger: Exploring Female Sexuality, edited by Carole S. Vance, 267-319. London: Pandora.

Thornton, Margaret. 2010. “'Post-Feminism' in the Legal Academy.” Feminist Review 95(1):9298.

Tomlinson, Barbara. 2017. "Category Anxiety and the Invisible White Woman: Managing Intersectionality at the Scene of Argument." Feminist Theory 19(2):145-64.

Triggs, Gillian. 2017. "Sexual Assault and Harassment on University Campuses: Changing the Course." Public lecture, Australian National University, September 5.

Walters, Suzanna Danuta. 2016. "Introduction: The Dangers of a Metaphor - Beyond the Battlefield in the Sex Wars." Signs 42(1):1-9

Willingham, Kamilah. 2016. "To the Harvard 19: Do Better." Huffington Post, December 6. http://www.huffingtonpost.com/kamilah-willingham/to-the-harvard-19-dobetter b 9547856.html.

- 2017. www.kamilahwillingham.com. 
Yoffe, Emily. 2015. "How The Hunting Ground Blurs the Truth.” Slate, June 1. https://slate.com/news-and-politics/2015/06/the-hunting-ground-a-closer-look-at-theinfluential-documentary-reveals-the-filmmakers-put-advocacy-ahead-of-accuracy.html.

—. 2017. "The Question of Race in Campus Sexual-Assault Cases: Is the System Biased against Men of Color?" The Atlantic, September 11. https://www.theatlantic.com/education/archive/2017/09/the-question-of-race-in-campussexual-assault-cases/539361/

${ }^{1}$ Title IX of the Education Amendments of 1972, 20 U.S.C. Â§1681 et seq.

${ }^{2}$ Critical legal theorist Janet Halley, discussed at length below is also involved in the debate around changes to Title IX; see: NPR (2017).

${ }^{3}$ In Australia, for instance, Universities Australia, in conjunction with the Human Rights Commission, undertook a nationwide survey of sexual assault on campus. Gillian Triggs (2017), president of the Human Rights Commission, publicly commented on The Hunting Ground as a spur to the survey.

${ }^{4}$ Though there were eighteen other signatories, Halley was listed as the first contact and acted as spokesperson in subsequent media on the press release, which was also signed by Elizabeth Bartholet, Scott Brewer, Charles Donahue Jr., Nancy Gertner, Bruce L. Hay, Philip B. Heymann, David W. Kennedy, Duncan M. Kennedy, Randall L. Kennedy, Charles J. Ogletree, Jr., Richard D. Parker, J. Mark Ramseyer, David Rosenberg, Lewis D. Sargentich, David L. Shapiro, Henry J. Steiner, Jeannie C. Suk, and Laurence H. Tribe.

${ }^{5}$ See Winston's website the Brandon Project (http://brandonproject.org/) and Willingham's website Kamilah Willingham (www.kamilahwillingham.com/). 
${ }^{6}$ This perpetuation of language around the "hunter/hunted" has continued in subsequent discussions of campus sexual assault; see, e.g., Oliver (2016).

${ }^{7}$ For example, in the infamous 1989 Central Park jogger case, five young black and Hispanic males were charged with the violent sexual assault of a white woman. The media used the trope of "wilding," which carries connotations of racialized savagery, to describe the young men's alleged behavior. See Duru (2004).

${ }^{8}$ Feminists have been making this argument for decades, for example see Frye $(1993,6)$. 


\section{University Library}

\section{- M M I N E R VA A gateway to Melbourne's research publications}

Minerva Access is the Institutional Repository of The University of Melbourne

Author/s:

Kennedy, R;McCann, H

Title:

Splitting from Halley: Doing Justice to Race, Unwantedness, and Testimony in Campus Sexual Assault

Date:

2020-09-01

Citation:

Kennedy, R. \& McCann, H. (2020). Splitting from Halley: Doing Justice to Race, Unwantedness, and Testimony in Campus Sexual Assault. SIGNS, 46 (1), pp.79-102. https:// doi.org/10.1086/709215.

Persistent Link:

http://hdl.handle.net/11343/254286 